\title{
THE ROLE OF PRESIDENT ABDEL FATTAH AL-SISI'S GOVERNMENT FOR THE DEVELOPMENT OF EGYPT'S POST-REVOLUTIONARY ECONOMIC REFORMS IN 2011
}

\author{
Virginia Sherin ${ }^{1}$ \\ Hardi Alunaza ${ }^{2}$ \\ ${ }^{1,2}$ Prodi Hubungan Internasional FISIP Universitas Tanjungpura \\ ${ }^{2}$ hardi.asd@fisip.untan.ac.id
}

\begin{abstract}
After the revolution in 2011, Egypt has experienced various conditions of instability in various fields, especially the economy and politics. The government of Mohammed Morsi, which was previously expected to be able to change the country's situation, actually made the Egyptian economy worse. Various demonstrations and other forms of protest were carried out by the Egyptian people so that the government could immediately improve the situation. However, the government failed to carry out conflict management so the military carried out a coup. Morsi's position was later replaced by Abdel Fattah AlSisi. Al-Sisi's background as a military figure led to repressive policies being implemented. During Al-Sisi's reign, there was a significant increase in the Egyptian economy. The purpose of this research is to identify the role of President Al-Sisi's government for the development of economic reform in Egypt after the 2011 Revolution. This research uses a qualitative approach with an exploratory type of research, and refers to the theory of liberalism and the rational actor model. The results of this research indicate that President Al-Sisi's policies have a positive impact on the development of the Egyptian economy as indicated by an increase in Egypt's Gross Domestic Product, a decrease in inflation rates, and poverty.
\end{abstract}

Keywords: Economic Reform, Middle East Politics, Repressive.

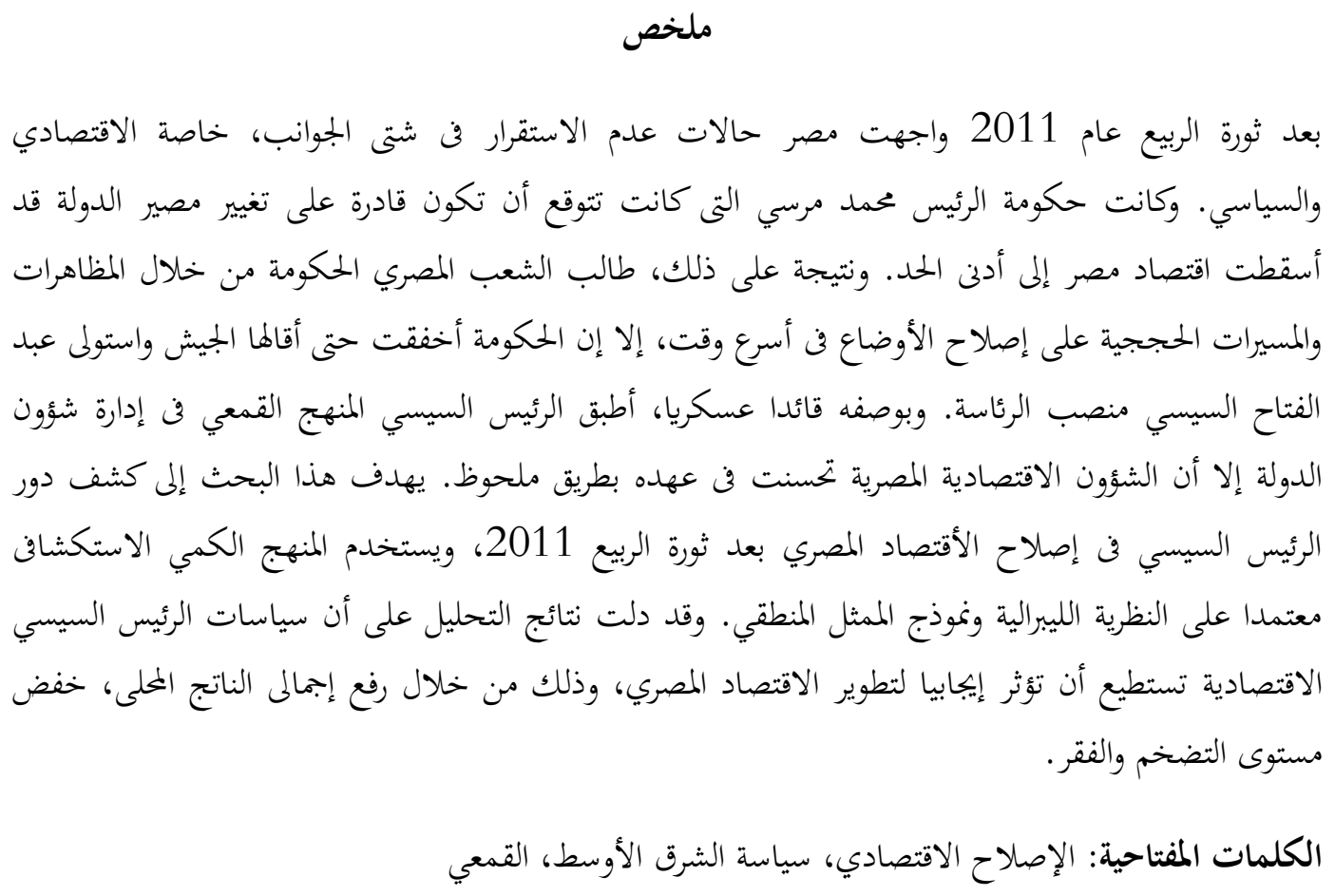




\section{A. Pendahuluan}

Mesir merupakan salah satu negara yang memiliki peradaban tertua di dunia. Negara ini telah melewati satu peristiwa besar yang memberikan dampak besar dalam perkembangan ekonomi, politik, dan sosial negaranya. Peristiwa yang terjadi pada tahun 2011 tersebut dikenal dengan Revolusi Mesir. Peristiwa itu diawali dari adanya pemberontakan rakyat Mesir terhadap pemerintahan otoriter Hosni Mubarak. Peristiwa tersebut berujung pada lengsernya Mubarak sebagai presiden Mesir pada masa itu, kemudian digantikan oleh Mohammed Morsi yang diusung oleh Partai Kebebasan dan Keadilan. Hal ini menunjukkan bahwa Morsi berhasil menjadi presiden sipil Mesir yang pertama (BBC Indonesia, 2013).

Kepemimpinan Morsi tidak berlangsung dengan lancar. Sejak Januari hingga Juli 2013, kerusuhan terus terjadi di Mesir sebagai aksi protes terhadap pemerintahan Mohammed Morsi. Ketika gelombang kerusuhan semakin meningkat, Abdel Fattah Al-Sisi, yang merupakan Menteri Pertahanan dan Komandan Angkatan Bersenjata mengatakan bahwa militer akan menjauhi politik sehingga tidak ada yang akan saling menyingkirkan satu sama lain. Pada Juni 2013, Al-Sisi menyerukan semua pihak untuk menggunakan jalur kompromi secara damai. Selain itu, ia berharap agar Morsi menyerukan pemilihan umum untuk dilaksanakan lebih awal. Akan tetapi, melalui pidatonya pada 26 Juni 2013, Morsi sama sekali tidak menunjukkan niat untuk menyelenggarakan pemilihan umum lebih cepat. Menurut laporan seorang perwira senior kepada The Guardian, dengan kondisi seperti itu, militer berpeluang besar untuk melengserkan jabatan Morsi (Kingsley, 2014).

Pada 1 Juli 2013, pihak oposisi memberikan Morsi waktu sebanyak satu hari untuk mengundurkan diri. Selain itu, militer Mesir juga memperingatkan bahwa intervensi maupun kudeta akan dilakukan apabila pemerintah tidak dapat memenuhi tuntutan rakyat dalam kurun waktu 48 jam. Kondisi tersebut diperparah ketika pada 2 Juli 2013, sebanyak 16 orang pendukung Morsi tewas dibunuh sekelompok pria bersenjata, sementara 200 orang pendukung lainnya luka-luka. Akhirnya, Abdel Fattah Al-Sisi memutuskan untuk melakukan penggulingan terhadap pemerintahan Morsi dan menunjuk Hakim Agung Mahkamah Konstitusi Mesir sebagai caretaker atau presiden sementara (Patnistik, 2013).

Presiden Abdel Fattah Al-Sisi secara resmi menjabat sebagai pemimpin Mesir sejak tahun 2014. Al-Sisi memiliki latar belakang sebagai seorang prajurit militer sehingga sosoknya dikenal sebagai individu yang memiliki pengaruh yang sangat kuat dalam urusan mengurus negara. Sebelum menjabat sebagai Presiden Mesir, Al-Sisi menjabat sebagai Menteri Pertahanan di tahun 2012 dan dikenal berhasil menghentikan gelombang demonstran yang dipandang sangat mengancam keamanan negara. Akan tetapi, pada tahun 2013, Al-Sisi melakukan kudeta militer dan berhasil menggulingkan Muhammad Mursi (Ananda, 2019). Al-Sisi berhasil menggantikan Mursi dengan memperoleh dukungan sebanyak 96,1\%.

Revolusi Mesir tahun 2011 telah menawarkan kesempatan bagi Mesir untuk mereformasi kebijakan ekonominya untuk membangun kembali Mesir pasca pergolakan besar. Devaluasi mata uang telah menyebabkan lonjakan harga kebutuhan dan negara terperosok ke dalam utang luar negeri yang besar (The Guardian, 2018).

Presiden Al-Sisi ingin memperbaiki kondisi yang terjadi di Mesir mengenai defisit anggaran, angka pengangguran yang tinggi, hyperinflation, kemiskinan, hingga permasalahan mengenai utang luar negeri. Al-Sisi mendorong langkahlangkah penghematan yang diharapkan dapat memajukan perekonomian Mesir. Al-Sisi kemudian mengadopsi semua kebijakan ekonomi, baik terkait ekonomi domestik, maupun internasional (BBC Indonesia, 2014). Meskipun dalam implementasinya, Al-Sisi cenderung menerapkan tindakan yang represif di 
bawah junta militernya dengan tujuan untuk memajukan perekonomian Mesir.

Berdasarkan latar belakang di atas, ditemukan identifikasi masalah sebagai berikut. Pertama, pasca Revolusi 2011, perekonomian Mesir mengalami penurunan yang ditandai dengan banyaknya pengangguran dan kemiskinan. Kedua, terpilihnya Abdel Fattah Al-Sisi sebagai Presiden Mesir sejak Juni 2014, diharapkan dapat memajukan perekonomian Mesir. Ketiga, Mesir kembali dipimpin oleh tokoh dari junta militer. Penulis menggunakan teori liberalisme untuk menjelaskan kebijakan ekonomi yang ditempuh oleh pemerintahan Presiden Al-Sisi yang bertujuan untuk melakukan reformasi di bidang perekonomian pasca terjadinya revolusi tahun 2011. Teori liberalisme ini berfokus pada adanya keterbukaan ekonomi yang dilakukan sebagai langkah untuk memajukan perekonomian negara, seperti adanya kerja sama dan investasi. Sedangkan, untuk melihat sikap dari Presiden Al-Sisi yang tergambar melalui kebijakan-kebijakannya, penulis menggunakan rational actor model. Model tersebut digunakan untuk menganalisis sikap rasionalitas yang dimiliki oleh Presiden Al-Sisi yang memperhitungkan cost and benefit dalam kerja sama ekonomi yang dilakukannya.

Sebelumnya, Robert Springborg (2017) melakukan penelitian yang membahas mengenai transisi ekonomi Mesir dari masa pemerintahan Mubarak ke Presiden Al-Sisi. Di dalam tulisannya, Springborg melihat bahwa rezim militer kembali menempati kekuasaan pada tahun 2013 yang kemudian mengisyaratkan bahwa sistem ekonomi kembali didominasi oleh peran elit militer yang homogen. Pemerintahan Al-Sisi juga membentuk sistem pemerintahan yang eksklusif, yang mana otoritas dalam pemerintahan secara umum hanya dijabat oleh elit-elit militer (Springborg, 2017). Tulisan ini menekankan pada pembahasan mengenai kebijakan ekonomi yang ditempuh oleh Presiden Al-Sisi pada tahun 2014-2018 dalam melakukan reformasi di Mesir setelah terjadinya revolusi dan kudeta terhadap kepemimpinan sebelumnya.

Penulis menggunakan desain penelitian kualitatif deskriptif yang bertujuan untuk mendeskripsikan atau menggambarkan suatu proses, fenomena, peristiwa, peran, maupun tindakan dari individu atau kelompok. Dalam penelitian ini, penulis mengumpulkan data melalui kegiatan studi literatur, yakni dengan melakukan penelusuran melalui media cetak maupun daring, buku, jurnal, dan artikel ilmiah. Penulis melakukan proses validasi data dengan teknik triangulasi sumber yang berasal dari penelitian terdahulu yang memiliki tema serupa dengan masalah yang diangkat dalam penelitian ini. Sementara itu, penulis mengadopsi teknik analisis data Miles dan Huberman dengan tahapan: 1) reduksi data, 2) penyajian data, dan 3) penarikan kesimpulan (Sugiyono, 2016, hal. 247).

\section{B. Kerangka Teori \\ 1. Liberalisme}

Dalam melihat fenomena ini, penulis menggunakan teori liberalisme menurut Zacher dan Matthew (1995) dalam (Jackson \& Sørensen, 2013) yang menitikberatkan pada proses modernisasi. Keduanya melihat bahwa apabila suatu negara melakukan proses modernisasi, maka akan tercipta ruang lingkup yang lebih luas bagi upaya kerja sama yang dilakukan antarnegara yang akan berdampak pada peningkatan ekonomi. Liberalisme juga melihat bahwa kerja sama merupakan cara terbaik untuk mencapai kepentingan yang diharapkan. Selain itu, adanya peran dan intervensi dari negara dalam menentukan regulasi pada bidang perekonomian ditujukan untuk memenuhi kebutuhan masyarakat dan mmperluas kerja sama (Dugis, 2016, hal. 61).

Terkait dengan kemajuan perekonomian, liberalisme menganut paham bahwa modernisasi merupakan suatu proses yang berpotensi untuk memberikan kemajuan dalam berbagai bidang. Proses modernisasi ini akan memperluas ruang lingkup dan jangkauan bagi hubungan atau kerja sama yang 
bersifat global. Ditunjang dengan keinginan yang kuat dari berbagai elemen dalam suatu negara untuk berkembang, kerja sama akan membawa kehidupan yang lebih baik bagi mayoritas individu. Dalam bidang ekonomi, modernisasi yang dilakukan oleh suatu negara bertujuan untuk mereformasi tatanan yang telah ada sebelumnya, baik menghilangkan, meningkatkan, ataupun menggabungkan tatanan sebelumnya dengan tatanan saat ini (Jackson \& Sørensen, 2013, hal. 177178).

Dalam proses modernisasi untuk menuju pada kemajuan ekonomi, peran negara juga diperlukan sebagai pembentuk kerangka aturan. Negara memainkan peran dalam mengarahkan berbagai kegiatan ekonomi, kerja sama, menarik pajak, hingga pengurangan subsidi (Steans \& Pettiford, 2009, hal. 105-107). Selain itu, didasari oleh kesadaran akan ketidakmampuan untuk memenuhi kebutuhan sendiri, telah membuat negaranegara di dunia merasa perlu untuk menjalin kerja sama satu sama lain. Dalam suasana kerja sama yang semakin intensif pada bidang tertentu, maka akan berimbas pada bidang lainnya, seperti kerja sama pada sektor energi, sumber daya alam, jalur perdagangan, dan lainnya. Dalam konteks ini, dapat diketahui bahwa keterbukaan ekonomi membawa pengaruh yang besar pada berbagai sendi kehidupan negara (Hadiwinata, 2017, hal. 90).

Teori ini membantu penulis dalam menjelaskan orientasi kebijakan Presiden Al-Sisi dalam agendanya untuk mereformasi ekonomi Mesir pasca revolusi 2011. Terkait hal ini, Presiden Al-Sisi telah membuka perekonomiannya dengan menjalin kerja sama dan investasi dengan negara lain. Ekonomi liberal melihat bahwa keterbukaan ekonomi dapat memberikan pengaruh yang signifikan bagi pertumbuhan dan kemajuan ekonomi suatu negara.

\section{Rational Actor Model}

Rational Actor Model merupakan sebuah model pengambilan keputusan yang didasarkan pada sifat rasionalitas aktor (decision-makers) yang didasarkan pada motif ekonomi atau utilitarianisme. Menurut Anthony Downs, model pengambilan keputusan ini memandang bahwa sifat dasar manusia adalah untuk mewujudkan keinginannya mengenai kepuasan untuk memiliki dan menguasai berbagai materi yang berkaitan dengan bermacam bentuk utilitas, seperti nilai, keseimbangan, serta kondisi yang ideal bagi dirinya (Afinotan, 2014, hal. 253). Untuk merumuskan suatu keputusan, aktor rasional perlu melewati serangkaian prosedur. Pertama, identifikasi masalah yang terjadi. Kedua, memilih tujuan dan sasaran yang didasarkan pada skala prioritas. Ketiga, peninjauan terhadap efektivitas, biaya, keuntungan, hingga kendala yang akan dihadapi untuk mencapai tujuan yang diharapkan. Keempat, untuk mewujudkan tujuan, maka keputusan yang dirumuskan harus dilaksanakan melalui sarana yang tepat (Heywood, 2011, hal. 129-130).

Hakikat manusia yang bekerja dengan cara yang rasional dan konsisten demi mencapai tujuannya, menjadi dasar bagi rational actor model ini untuk menekankan pada analisis cost and benefit dalam proses pengambilan keputusan. Analisis cost and benefit memiliki prinsip untuk memperbesar pendapatan dan memperkecil pengeluaran. Artinya, implementasi keputusan ditujukan untuk memperoleh manfaat dan keuntungan yang sebesar-besarnya (Sitepu, 2011, hal. 94-95). Dalam konteks negara, hanya terdapat satu tujuan tunggal aktor rasional dalam merumuskan kebijakannya, yakni mewujudkan kepentingan nasional sebagai penjamin utama kelangsungan hidup negara berdasarkan beberapa konsekuensi yang telah dipertimbangkan (Heywood, 2011, hal. 130). Penulis menggunakan konsep rational actor model untuk menganalisis kebijakan yang bertujuan untuk mereformasi ekonomi pasca revolusi, yang dikeluarkan oleh pemerintahan Mesir pada masa kepemimpinan Presiden Al-Sisi yang bersikap rasional dalam setiap langkah yang diambilnya. 


\section{Hasil dan Pembahasan}

\section{Bentuk Kebijakan Pemerintahan Presiden Al-Sisi terkait Reformasi \\ Ekonomi Mesir Pasca Revolusi 2011}

Perekonomian Mesir pasca revolusi

2011 berada pada kondisi yang buruk. Defisit anggaran meningkat dari 8,1 persen di tahun 2010 menjadi 10 persen di tahun 2011. Selain itu, terjadi peningkatan harga pangan dan bahan bakar sehingga berimplikasi pada meningkatnya inflasi dari 11,7 persen di tahun 2010 menjadi 13,4 pada tahun 2011 (Abdou \& Zaazou, 2013, hal. 92). Terkait hal ini, hingga pada Agustus 2015, kinerja Presiden Al-Sisi ditunjukkan melalui keberhasilan Mesir dalam membuka perluasan Terusan Suez yang dibutuhkan untuk meningkatkan perekonomian negaranya yang sempat terpuruk saat terjadi pergolakan pada 2011 (Nugraha, 2015). Presiden Al-Sisi gencar melakukan pengembangan Terusan Suez dengan meluncurkan mega proyek yang terdiri dari pembangunan terusan baru yang terhubung dengan Terusan Suez, pembangunan jalan, serta terowongan di sekitar kawasan. Proyek pengembangan tersebut memerlukan total biaya sebesar USD 8 miliar yang dibiayai melalui peluncuran sertifikat investasi Terusan Suez yang dikhususkan untuk masyarakat Mesir. Selanjutnya, Presiden Al-Sisi mengumumkan bahwa mitra kerja sama Dar Al Handasah, ditugaskan untuk mengelola pengembangan proyek investasi di sepanjang Terusan Suez. Pendapatan yang diperoleh Mesir melalui perluasan Terusan Suez sebagai sektor penghasil devisa mencapai rata-rata USD 5 miliar setiap tahunnya (Sutedja, 2015, hal. 5).

Selanjutnya, dalam agenda ekonomi tahun 2016-2017, Al-Sisi menerapkan pemangkasan subsidi bahan bakar hingga 43\% dari total subsidi sebesar 61 miliar Pound Mesir pada 2015-2016. Tujuannya adalah sebagai upaya penghematan anggaran fiskal yang dapat digunakan untuk menutupi ketimpangan anggaran yang terdapat di bidang ekonomi lainnya. Selain itu, terdapat kebijakan investasi asing, kerja sama ekonomi dengan negara lain, seperti Tiongkok, Jepang, hingga Indonesia (Chandra, 2016).

Sementara itu, Mesir juga melakukan kerja sama dengan beberapa negara. Pada tahun 2016, Presiden Tiongkok, Xi Jinping, mengungkapkan kesediannya untuk mendukung upaya Mesir dalam menjaga stabilitas dan menempuh jalur pembangunan yang sesuai dengan kondisi domestik Negara Mesir. Tiongkok dan Mesir juga berkomitmen untuk saling mendukung terkait tantangan-tantangan yang dihadapi, serta terkait tindakan konkret untuk mempromosikan kerja sama ekonomi dan perdagangan bilateral kedua negara. Presiden Xi Jinping dalam hal ini, menyatakan kepuasannya atas kemajuan dalam kemitraan stategis yang komprehensif antara Tiongkok dan Mesir, yang diharapkan dapat meningkatkan kapasitas industri, keuangan, lapangan pekerjaan, dan pembangunan infrastruktur. Dengan diundangnya Presiden Al-Sisi dalam Konferensi Tingkat Tinggi (KTT) G-20 yang diselenggarakan di Hangzhou, Tiongkok pada September 2016, ia berharap Mesir dapat memperkuat hubungan bilateral dengan Tiongkok dalam bidang seperti industri, pertanian, telekomunikasi, keuangan, hidrologi, hingga sumber daya manusia (Pars Today, 2016).

Pada tahun 2017, jumlah kuantitas ekspor Mesir ke Tiongkok meningkat hingga $60 \%$. Angka tersebut terbilang tinggi dibandingkan tahun-tahun sebelumnya. Artinya, prospek dari kerja sama Mesir-Tiongkok ini berpeluang besar dalam upaya pembangunan kembali perekenomian Mesir. Kerja sama dalam bidang perdagangan dan industri antara Mesir dan Tiongkok menunjukkan bahwa Presiden Al-Sisi berusaha menjadikan Mesir sebagai pusat komersial dan logistik untuk akses produk-produk Tiongkok ke Afrika dan Eropa. Mesir juga menjadi salah satu sasaran investasi Tiongkok, mengingat potensi dari Terusan Suez yang dimiliki oleh Mesir (Egypt Today, 2018).

Selain menjalin kerja sama dengan Tiongkok, Mesir juga menjalin kerja sama dengan Jepang. Hal ini dibuktikan melalui 
pertemuan Presiden Al-Sisi dengan Perdana Menteri (PM) Shinzo Abe pada KTT G-20 di Hangzhou, Tiongkok pada September 2016. Presiden Al-Sisi menyatakan harapannya untuk memperkuat kerja sama bilateral dengan Jepang, terutama dalam bidang investasi, ekonomi, dan pendidikan. PM Shinzo Abe selanjutnya menegaskan bahwa ke depannya, Jepang dan Mesir sepakat untuk melangsungkan beberapa proyek dalam bidang energi dan infrastruktur. Selain itu, dalam bidang sosial, Jepang dan Mesir berkomitmen untuk mendorong kerja sama budaya, ilmu pengetahuan, dan teknologi (Voice of Vietnam, 2016).

Kerja sama bilateral antara kedua belah pihak meliputi beberapa bidang, seperti proyek infrastruktur, listrik, dan perdagangan. Pada tahun 2015, PM Shinzo Abe menawarkan pinjaman USD 388 juta bagi Mesir untuk pembangunan proyek bandara dan jaringan listrik. Pada tahun 2016, beberapa perusahaan Jepang mulai berinvestasi di Mesir dengan total investasi sebesar USD 17,7 miliar. Kemudian, masih pada tahun yang sama, Japan International Company Agency (JICA) memberikan pinjaman sebesar USD 450 juta untuk mendanai sektor energi dan transportasi di Mesir. Pada tahun 2017, nilai pertukaran perdagangan antara Mesir dan Jepang mencapai USD 1,8 miliar. Selain itu, terdapat 50 perusahaan Jepang yang berinvestasi di Mesir. Investasi ini menunjukkan adanya kepercayaan yang tinggi dari investor terhadap potensi yang dimiliki oleh Mesir (Ali, 2018).

Mesir juga menjalin hubungan dengan Indonesia di mana dalam salah satu kunjungannya ke Indonesia pada September 2015, Presiden Al-Sisi dan Presiden Joko Widodo menyetujui kesepakatan kerja sama untuk meningkatkan perekonomian kedua negara khususnya di bidang investasi dan perdagangan. Presiden Joko Widodo menilai bahwa kesepakatan tersebut sebagai langkah yang tepat mengingat besarnya jumlah investasi Indonesia yang ada di Mesir. Pemerintah Indonesia berharap agar Mesir dapat mempermudah upaya investor dari Indonesia untuk melakukan investasi di Negara Mesir. Mesir merupakan mitra ekonomi terbesar Indonesia di lingkup Asia-Afrika dengan total pendapatan dari sektor perdagangan mencapai USD 1,5 miliar. Presiden AlSisi menyetujui langkah Indonesia untuk memperluas kerja sama di bidang perdagangan, serta keinginan kedua negara untuk menggunakan Terusan Suez sebagai jalur ekonomi dan investasi (Armenia, 2015).

Pada tahun 2017, Menteri Luar Negeri Indonesia dan Menteri Kerja Sama Internasional Mesir yakni Sahar Nasr, memutuskan untuk melakukan kerja sama dalam meningkatkan diplomasi ekonomi antara kedua negara. Retno Marsudi selaku Menteri Luar Negeri Indonesia mengatakan bahwa potensi yang dimiliki oleh negara-negara di Benua Afrika termasuk Mesir, cukup kuat untuk memajukan unit-unit perekonomian rakyat, salah satunya Usaha Kecil dan Menengah (UKM). Mengingat peluang pada arus globalisasi perlu dimanfaatkan sebaik mungkin, Mesir dan Indonesia sepakat untuk mendorong kemajuan UKM agar sektor perekonomian masyarakat mendapat perhatian yang lebih baik (Kementerian Luar Negeri RI, 2017).

Kedua belah pihak juga telah melangsungkan konsultasi bilateral pada April 2017 yang menjadi dasar bagi terwujudnya kesepakatan untuk mengintensifkan kerja sama ekonomi antarnegara, khususnya dalam bidang perdagangan. Kerja sama ekonomi Mesir dan Indonesia dinilai memberikan pengaruh yang signifikan, terutama saat pemerintahan Presiden Al-Sisi. Terhitung pada Januari-Oktober 2016, nilai perdagangan bilateral antara Mesir dan Indonesia mencapai USD 1,23 miliar (Kementerian Luar Negeri RI, 2017). Agenda-agenda tersebut merupakan wujud kinerja yang dilakukan oleh pemerintahan Mesir pada era Presiden Al-Sisi bagi reformasi dan kebangkitan perekonomian negaranya pasca terjadinya revolusi tahun 2011 yang telah membawa permasalahan krusial dan fundamental bagi perkembangan Mesir. 
Tidak hanya sebatas kerja sama antar negara, Mesir juga melakukan pendekatan terhadap lembaga internasional. Pada November 2016, Mesir mendapatkan pinjaman sebesar USD 12 miliar dari IMF. Pinjaman tersebut dimaksudkan untuk membantu meningkatkan perekonomian Mesir yang sedang mengalami keterpurukan (Hadid, 2016). Kepala Misi IMF, Chris Jarvis mengatakan bahwa Mesir merupakan negara yang memiliki potensi besar, tetapi memiliki beberapa masalah yang perlu segera diatasi. Hal tersebut yang melandasi IMF memberikan pinjaman kepada Mesir. Program bantuan dari IMF bertujuan untuk menurunkan defisit anggaran dan utang pemerintah. Kemudian, menciptakan lapangan kerja untuk mengurangi pengangguran dan tingkat kemiskinan (CNBC, 2016).

Selanjutnya, pada September 2018, berdasarkan kesepakatan Presiden Al-Sisi dengan Presiden World Bank, Jim Yong Kim, IMF akan kembali memberikan pinjaman kepada Mesir sebesar USD 3 miliar. Proses peminjaman itu difasilitasi karena kepercayaan World Bank dan IMF dalam program reformasi ekonomi Mesir pada masa kepemimpinan Presiden AlSisi. Menurut Direktur Eksekutif IMF, Hazim Al-Beblawi, Mesir ditargetkan selesai melunasi dana pinjaman ini pada tahun 2019. Al-Beblawi berpandangan optimis terkait hal tersebut karena Mesir berhasil melaksanakan semua program reformasi ekonomi dengan efisien (Tawfeek, 2018).

\section{Dampak Positif Kebijakan Presiden Al-Sisi bagi Pertumbuhan Ekonomi Mesir}

Ekonomi Mesir mulai pulih pada masa pemerintahan Presiden Al-Sisi. Hal tersebut didukung oleh kebijakan ekonomi makro dan reformasi awal yang terus menunjukkan peningkatan signifikan dengan tujuan untuk mengatasi tantangan utama yang dihadapi oleh sektor perekonomian dalam beberapa tahun terakhir. Berdasarkan laporan dari IMF, setelah lebih dari satu tahun sejak peluncuran program reformasi ekonomi,

pertumbuhan PDB Mesir semakin menguat dan inflasi semakin menurun (International Monetary Fund, 2018). Produk Domestik Bruto (PDB) di Mesir meningkat $5,4 \%$ pada kuartal kedua tahun 2018. Angka ini menunjukkan tren peningkatan dibandingkan periodeperiode sebelumnya. Pada kuartal akhir di tahun 2018, tingkat pertumbuhan PDB Mesir diperkirakan meningkat hingga 5,6\%, menurut laporan dari Trading Economics. Dalam jangka panjang, tingkat pertumbuhan PDB Mesir diproyeksikan mencapai 5,8\% pada tahun 2020 (Trading Economics, 2018).

Dalam hal ini, pemerintahan Presiden Al-Sisi tentunya memberikan peran yang cukup penting terkait peningkatan angka pertumbuhan PDB Mesir, mengingat pada tahun 2008 hingga tahun 2010, PDB Mesir sempat terpuruk. Mesir mencapai tingkat pertumbuhan PDB tertinggi sepanjang sejarah, pada masa pemerintahan Presiden Al-Sisi tepatnya pada tahun 2016, ketika PDB Mesir mencapai USD 332 miliar (International Monetary Fund, 2018). Tingkat inflasi Mesir juga menurun seiring dengan pemangkasan subsidi bahan bakar, serta penerapan pajak penjualan alkohol dan rokok. Pemerintah memangkas defisit anggaran dengan meningkatkan promosi pariwisata, dan meningkatkan kembali cadangan devisa negara. Subir Lall, kepala tim IMF mengatakan bahwa perputaran makroekonomi dalam negeri Mesir dan lingkungan ekonomi global yang mendukung, telah memberikan kesempatan besar bagi kebijakan reformasi struktural yang diperlukan untuk meningkatkan perekonomian Mesir. Langkah pemerintahan Presiden Al-Sisi telah menciptakan iklim yang tepat bagi reformasi ekonomi pasca revolusi 2011 (Yekaterina, 2015).

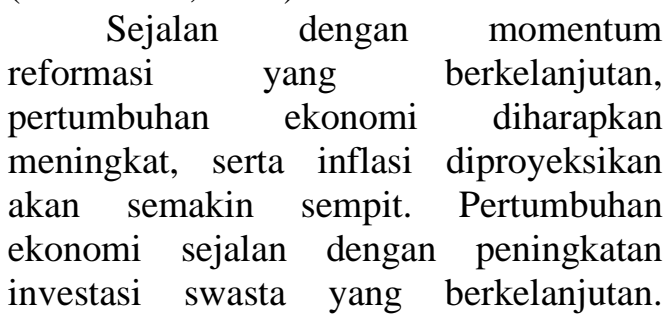


Selain itu, sebagian pendapatan negara diperoleh dari peningkatan ekspor gas alam, serta berasal dari sektor pariwisata. Pemerintah Mesir juga optimis terkait penurunan defisit anggaran karena didukung oleh peningkatan penerimaan Pajak Pertambahan Nilai (PPN) serta adanya subsidi bahan bakar. Oleh karena itu, World Bank memperkirakan defisit anggaran Mesir akan turun menjadi 4,9\% dari PDB pada kuartal akhir 2018, dibanding dengan $6,6 \%$ dari PDB pada kuartal akhir 2017 (World Bank, 2018).

Lebih lanjut, laporan dari World Bank menunjukkan bahwa angka kemiskinan di Mesir berhasil dikurangi. Sekitar $27,8 \%$ penduduk berada di bawah garis kemiskinan yang diakibatkan oleh revolusi pada tahun 2011. Kini, angka tersebut mulai menurun seiring dengan adanya program tunjangan sosial dari pemerintah, sehingga tingkat kesenjangan terus menurun. Pada pemerintahan sebelumnya, kesenjangan antara penduduk pedesaan dan perkotaan terlihat sangat jelas. Namun, dengan program pemerintahan Presiden Al-Sisi beberapa tingkat kesenjangan mulai berkurang, yang ditandai dengan program pembangunan infrastruktur, hingga investasi yang merata (World Bank, 2018).

Untuk mendukung reformasi dalam negeri, pada November 2016, pemerintah Mesir memulai langkah-langkah untuk memulihkan stabilitas keuangan negara dengan mendorong pertumbuhan dan kesempatan kerja, serta melindungi masyarakat berpenghasilan rendah dari dampak buruk revolusi 2011 tersebut. Sebagai hasilnya, pemerintah Mesir telah sanggup membayar angsuran Extended Fund Facility (EFF) atau Fasilitas Dana Perpanjangan dari IMF sebesar USD 12 miliar pada 20 Desember 2017. EFF merupakan dana pinjaman yang diberikan oleh IMF ketika suatu negara menghadapi masalah ketimpangan antara pendapatan negara dan pengeluaran anggaran karena berbagai permasalahan struktural (International Monetary Fund, 2018).

\section{Peran Pemerintahan Presiden Abdel Fattah Al-Sisi bagi Perkembangan Reformasi Ekonomi Mesir Pasca Revolusi 2011}

Berdasarkan teori liberalisme, adanya jalinan kerja sama dengan pihak eksternal bertujuan untuk membangun perekonomian. Asumsi utama mengenai kesejahteraan didasari oleh adanya keterbukaan ekonomi. Dengan berdasar pada keterbukaan ekonomi, serta kesadaran akan ketidakmampuan negara untuk memenuhi kebutuhan sendiri, maka tercipta suatu kondisi di mana aktor-aktor ekonomi saling bekerja sama. Tujuannya adalah untuk memenuhi kebutuhan dan meningkatkan keuntungan yang diperoleh melalui perdagangan dan investasi. Peran negara dalam hal ini adalah sebagai perumus kebijakan yang digunakan sebagai aturan resmi dan sah terkait jalannya kegiatan perekonomian (Hadiwinata, 2017).

Dalam perkembangannya, kebijakan Presiden Al-Sisi telah berhasil menyumbang peningkatan angka pendapatan negara dan besaran investasi, hingga menurunkan angka kemiskinan. Pemerintah Mesir melakukan reformasi ekonomi yang ditunjukkan dari adanya peluncuran proyek serta berbagai program berskala nasional yang ditujukan untuk meningkatkan pendapatan negara dengan didukung oleh investasi dari pihak eksternal, seperti Tiongkok dan Jepang. Terkait dengan reformasi ekonomi, berbagai langkah dilakukan, termasuk melanjutkan upaya untuk memperkuat kemitraan ekonomi dan hubungan kerja sama internasional (Hasan, 2018).

Pemulihan ekonomi menjadi prioritas utama kebijakan nasional Mesir pada masa pemerintahan Presiden Al-Sisi. Secara umum, program ekonomi Mesir terdiri dari pemangkasan subsidi, penarikan pajak yang ketat, menarik investasi asing, meningkatkan ekspor gas alam, mempromosikan sektor pariwisata, hingga peluncuran mega proyek dalam perluasan Terusan Suez. Pada rezim sebelumnya, program subsidi telah menyumbangkan masalah utama bagi defisit anggaran negara Mesir. Subsidi 
listrik, gas, dan bahan bakar minyak telah banyak membebani anggaran ekonomi pemerintah. Melalui kebijakannya, Presiden Al-Sisi telah memangkas berbagai program subsidi sehingga Mesir dapat menghemat anggaran fiskal mencapai USD 40 miliar. Terkait dengan perluasan Terusan Suez, pemerintah menargetkan pendapatan dari lalu lintas kapal tahunan meningkat dari USD 5 miliar pada 2015 menjadi USD 13 miliar pada tahun 2023, serta diharapkan dapat menarik minat investor asing sehingga dapat menciptakan lapangan pekerjaan bagi masyarakat Mesir (Pars Today, 2016).

Teori liberalisme melihat bahwa keterbukaan ekonomi Mesir pada masa pemerintahan Presiden Al-Sisi mengambil andil yang besar dalam peningkatan pendapatan negara. Pada faktanya, kebijakan pemerintah dalam bidang perekonomian telah membawa pengaruh positif yang signifikan bagi pertumbuhan PDB, penurunan inflasi, hingga pengentasan kemiskinan. Kebijakan politik dari pemerintah sangat dibutuhkan untuk mengatur dan menentukan arah perekonomian agar kepentingan nasional negara dapat terwujud. Sebagai seorang pemimpin, merupakan hal yang wajar apabila Presiden Al-Sisi memiliki tujuan dan cita-cita untuk memperbaiki kondisi ekonomi Mesir yang terpuruk akibat pergolakan politik struktural yang sempat melanda negaranya (VOA Indonesia, 2018).

Meskipun sempat menurun, PDB Mesir diproyeksikan akan terus meningkat seiring dengan banyaknya jalinan kerja sama ekonomi terutama perdagangan dengan negara-negara lainnya. Selain itu, dengan keterbukaan dan perluasan Terusan Suez, banyak negara yang optimis dengan pertumbuhan ekonomi Mesir pada pemerintahan Presiden AlSisi. Hal ini terlihat dari kepercayaan IMF untuk memberikan pinjaman dana serta banyaknya negara-negara yang melakukan kerja sama ekonomi, hingga menanamkan investasinya di Mesir (Trading Economics, 2018).
Selanjutnya, menurut rational actor model, Presiden Al-Sisi cenderung memperhitungkan cost and benefit dalam langkah-langkah kebijakannya. Hal pertama yang dilakukan Presiden Al-Sisi saat terpilih menjadi presiden adalah memprioritaskan perluasan Terusan Suez. Terusan Suez memberikan dampak positif yang cukup signifikan dalam meningkatkan perekonomian Mesir, karena tarif atau bea masuk yang diberlakukan bagi kapal-kapal yang melintas, menyumbangkan pendapatan hingga USD 5 miliar setiap tahunnya. Selain itu, Terusan Suez meningkatkan posisi tawar yang tinggi bagi Mesir dalam pelayaran dan perdagangan internasional. Hal tersebut dikarenakan Terusan Suez menghubungkan Benua Eropa dengan Benua Asia, Afrika, dan kawasan Timur Tengah (Sutedja, 2015).

Model aktor rasional menyatakan bahwa pengalaman pribadi, pandangan psikologis, dan pengalaman sejarah yang pernah dialami menjadi pertimbangan utama seorang aktor, sehingga ia cenderung bersikap rasional dalam merumuskan keputusan. Presiden Al-Sisi yang merupakan seorang pimpinan militer yang mengalami dan melihat terjadinya revolusi masyarakat Mesir secara langsung, tentunya merasa terdorong untuk melakukan reformasi agar berbagai dampak negatif yang merupakan hasil dari pergolakan tersebut dapat teratasi dan perekonomian negaranya tidak semakin terpuruk. Presiden Al-Sisi memutuskan untuk meluncurkan program reformasi ketika ekonominya menghadapi kondisi ketidakseimbangan yang menyebabkan melemahnya pertumbuhan, utang luar negeri yang tinggi, defisit neraca anggaran yang meningkat, dan menurunnya cadangan devisa tahunan (International Monetary Fund, 2018). Meskipun tergolong menerapkan kebijakan yang represif, langkah Presiden Al-Sisi terbukti banyak memberikan dampak positif bagi pertumbuhan ekonomi Mesir.

\section{Kesimpulan}

Revolusi tahun 2011 yang ditandai dengan lengsernya Hosni Mubarak, telah 
mengakibatkan terjadinya kondisi instabilitas dalam perekonomian Mesir. Hal tersebut memerlukan perhatian dari pemerintah, sehingga diharapkan kondisi keterpurukan ekonomi tidak terus berlanjut. Terpilihnya Mohammed Morsi, tidak lantas membawa Mesir ke arah yang lebih baik. Berbagai aksi demonstrasi dilakukan untuk melengserkan jabatannya. Akibat ketidakmampuan pemerintah untuk mengakomodasi tuntutan rakyat, militer akhirnya melakukan kudeta pada masa kepemimpinan Morsi. Lengsernya Morsi kemudian digantikan oleh Presiden AlSisi yang merupakan tokoh militer. Terpilihnya Presiden Al-Sisi menandakan adanya dukungan dan keinginan rakyat Mesir terhadap sosok pemimpin yang tegas untuk kembali memimpin Mesir setelah berakhirnya kepemimpinan Mohammed Morsi. Meskipun dinilai menerapkan kebijakan yang represif, seperti memangkas subsidi dan menarik pajak, kebijakan ekonomi Mesir saat kepemimpinan Presiden Al-Sisi berorientasi ke arah yang semakin baik. Hal tersebut ditunjukkan dengan peningkatan PDB Mesir, serta menurunnya tingkat inflasi dan angka kemiskinan. Berbagai jalinan kerja sama dengan negara lain juga terus ditingkatkan. Selain itu, dengan adanya perluasan Terusan Suez, pendapatan negara Mesir terus bertambah serta posisi tawar negara juga meningkat, mengingat Terusan Suez memiliki posisi yang strategis sebagai jalur pelayaran internasional. Berdasarkan pada hal tersebut, kebijakan Presiden Al-Sisi dinilai berdampak positif bagi perkembangan reformasi ekonomi Mesir pasca revolusi tahun 2011.

\section{DAFTAR PUSTAKA}

Abdou, D. S., \& Zaazou, Z. (2013). The Egyptian Revolution and Post Socio-Economic Impact. Topics in Middle Eastern and African Economies, 15(1).

Afinotan, L. A. (2014). Decision Making in International Relations: A
Theoretical Analysis. Canadian Social Science, 10(5).

Ali, W. (2018). Shoukry to discuss cooperation between Egypt, Japan Wednesday. Dipetik Agustus 02, 2021, dari Egypt Today: http://www.egypttoday.com/Article/ 2/58464/Shoukry-to-discusscooperation-between-Egypt-JapanWednesday.

Ananda, R. (2019). Analisis Faktor Kepemimpinan terhadap Pelanggaran HAM di Mesir oleh Rezim Abdel Fattah Al-Sisi. Journal of International Relations, 5(1), 292.

Armenia, R. (2015). Indonesia-Mesir Sepakat Tingkatkan Kerjasama Ekonomi. Dipetik Agustus 02, 2021, dari CNN Indonesia: https://www.cnnindonesia.com/inter nasional/20150905005402-127-

76760/indonesia-mesir-sepakattingkatkan-kerjasama-ekonomi.

BBC Indonesia. (2013). Protes di Mesir Berujung Kekerasan. Dipetik Agustus 01, 2021, dari BBC News Company:

https://www.bbc.com/indonesia/dun ia/2013/07/130701_mesir_bentrok.

BBC Indonesia. (2014). Presiden Mesir Abdul Fattah Al-Sisi Diambil Sumpah. Dipetik Agustus 01, 2021, dari BBC News Company: https://www.bbc.com/indonesia/dun ia/2014/06/140608_mesir_presiden.

Chandra, A. A. (2016). Mesir Bakal Pangkas Subsidi BBM Hingga 43\%. Dipetik Agustus 02, 2021, dari Detik Finance: https://finance.detik.com/energi/d3184075/mesir-bakal-pangkassubsidi-bbm-hingga-43.

CNBC. (2016). IMF agrees to $\$ 12$ billion 3-year loan deal for Egypt. Dipetik 
Agustus 02, 2021, dari CNBC International:

https://www.cnbc.com/2016/08/11/i mf-agrees-12-billion-3-year-loandeal-for-egypt.html.

Dugis, V. (Penyunt.). (2016). Teori Hubungan Internasional: Perspektif-Perspektif Klasik. Surabaya: PT. Revka Petra Media.

Egypt Today. (2018). Egypt's Exports to China Record \$408M in 2017. Dipetik Agustus 02, 2021, dari Egypt Today: http://www.egypttoday.com/Article/ 3/53547/Egypt\%E2\%80\%99sexports-to-China-record-408M-in2017.

Hadid, D. (2016). Painful Steps Help Egypt Secure \$12 Bilion I.M.F. Loan. Dipetik Agustus 02, 2021, dari The New York Times: https://www.nytimes.com/2016/11/ $12 /$ world/middleeast/egypt-getsfinal-imf-approval-for-12-billionloan.html.

Hadiwinata, B. S. (2017). Studi dan Teori Hubungan Internasional: Arus Utama, Alternatif, dan Reflektivis. Jakarta: Yayasan Pustaka Obor Indonesia.

Halin, H. H. (2016). Kondisi Mesir tahun 2011 -2012 dan Reaksi Dunia Pasca Runtuhnya Rezim Mubarak karena Revolusi Mesir 2011. Jurnal Analisis Hubungan Internasional, 5(1), 250.

Hasan, R. A. (2018). Presiden Mesir Abdel Fattah Al-Sisi Dilantik untuk Periode Jabatan Kedua. Dipetik Agustus 02, 2021, dari Liputan 6 News:

https://www.liputan6.com/global/re $\mathrm{ad} / 3547348 /$ presiden-mesir-abdelfattah-al-sisi-dilantik-untukperiode-jabatan-kedua.
Heywood, A. (2011). Global Politics. New York: Palgrave Macmillan.

International Monetary Fund. (2018). Egypt: Time to Entrench Growth and make it more Inclusive. Dipetik Agustus 02, 2021, dari IMF Country Focus: https://www.imf.org/en/News/Articl es/2018/01/22/na012318-egypttime-to-entrench-growth-and-makeit-more-inclusive.

Jackson, R., \& Sørensen, G. (2013). Pengantar Studi Hubungan Internasional: Teori dan Pendekatan. Yogyakarta: Pustaka Pelajar.

Kementerian Luar Negeri RI. (2017). Indonesia-Mesir Sepakat Tingkatkan Kerjasama Ekonomi. Dipetik Agustus 02, 2021, dari Kementerian Luar Negeri RI: https://www.kemlu.go.id/id/berita/P ages/Indonesia-Mesir-SepakatTingkatkan-Kerja-SamaEkonomi.aspx.

Kingsley, P. (2014). Abdel Fatah Al-Sisi: Behind the Public Face of Egypt's soon-to-be President. Dipetik Agustus 01, 2021, dari The Guardian: https://www.theguardian.com/world /2014/may/22/abdel-fatah-al-sisiegypt-president.

Mushlih, A. (2016). Aktor Politik dan Gagalnya Transisi Demokrasi Mesir Tahun 2011-2013. Jurnal Politik, 2(1), 42.

Nugraha, F. (2015). Mesir Perluas Terusan Suez. Dipetik Agustus 02, 2021, dari Metro TV News Internasional:

http://internasional.metrotvnews.co m/dunia/MkM6RMEK-mesirperluas-terusan-suez. 
Pars Today. (2016). Cina dan Mesir Tekankan Perluasan Kerjasama. Dipetik Agustus 02, 2021, dari Pars Today: http://parstoday.com/id/news/world -i19600-

cina_dan_mesir_tekankan_perluasa n_kerjasama.

Pars Today. (2016). Transformasi Mesir di Era Jenderal al-Sisi (1). Dipetik Agustus 02, 2021, dari Pars Today: http://parstoday.com/id/radio/world -i3139-

transformasi_mesir_di_era_jenderal _al_sisi_(1).

Patnistik, E. (2013). Kronologi Kejatuhan Muhammad Mursi. Dipetik Agustus 01, 2021, dari Kompas: https://internasional.kompas.com/re $\mathrm{ad} / 2013 / 07 / 04 / 1104085 /$ Kronologi. Kejatuhan.Muhammad.Mursi.

Setiawan, A. (2015). Diplomatic Dilemma dan Standar Ganda Politik Amerika Serikat terhadap Konflik SipilMiliter Mesir Tahun 2013. Jurnal Hubungan Internasional, 4(1), 70.

Sitepu, P. A. (2011). Studi Hubungan Internasional. Yogyakarta: Graha Ilmu.

Springborg, R. (2017). Egypt's Economic Transition: Challenges and Prospects. Dalam G. Luciani, Combining Economic and Political Development: The Experience of MENA. Leiden: Brill.

Steans, J., \& Pettiford, L. (2009). Hubungan Internasional: Perspektif dan Tema. Yogyakarta: Pustaka Pelajar.

Sugiyono. (2016). Metode Penelitian Kuantitatif, Kualitatif, dan $R \& D$. Bandung: Alfabeta.
Sutedja, L. N. (Penyunt.). (2015). Potensi Pasar Bisnis di Mesir. Cairo: KBRI Cairo.

Tawfeek, F. (2018). IMF to give Egypt new \$3 billion grant: Investment Minister. Dipetik Agustus 02, 2021, dari Egypt Independent: https://ww.egyptindependent.com/i mf-to-give-egypt-new-3-billiongrant-investment-minister/.

The Guardian. (2018). The Guardian view on Egyptian Democracy: It would be a Good Idea. Dipetik Agustus 01, 2021, dari The Guardian Opinion:

https://www.theguardian.com/com mentisfree/2018/jan/15/theguardian-view-on-egyptiandemocracy-it-would-be-a-goodidea.

Trading Economics. (2018). Egypt GDP. Dipetik Agustus 02, 2021, dari Trading Economics: dari https://tradingeconomics.com/egypt /gdp.

Trading Economics. (2018). Egypt GDP Growth Rate. Dipetik Agustus 02, 2021, dari Trading Economics: https://tradingeconomics.com/egypt /gdp-growth.

VOA Indonesia. (2018). Presiden Mesir Bela Kebijakan Penghematan Listrik dan Air. Dipetik Agustus 02, 2021, dari VOA Indonesia: https://www.voaindonesia.com/a/pr esiden-mesir-bela-kebijakanpenghematan-listrik-danair/4436814.html.

Voice of Vietnam. (2016). Mesir dan Jepang Memperkuat Kerjasama di Banyak Bidang. Dipetik Agustus 02, 2021, dari Departemen Siaran Luar Negeri Vietnam (VOV5): http://vovworld.vn/idID/berita/mesir-dan-jepang- 
memperkuat-kerjasama-di-banyakbidang-467131.vov.

World Bank. (2018). Egypt's Economic Outlook-April 2018. Dipetik Agustus 02, 2021, dari World Bank: https://www.worldbank.org/en/coun try/egypt/publication/economicoutlook-april-2018.
Yekaterina. (2015). Egypt Inflation Rate Lowest in more than 2 years. Dipetik Agustus 02, 2021, dari Trading Economics Articles: https://tradingeconomics.com/articl es/09102015124359.html. 